\title{
PENGEMBANGAN TRAINER MIKROKONTROLER BERBASIS ARDUINO NANO PADA MATA PELAJARAN TEKNIK PEMROGRAMAN, MIKROPROSESOR DAN MIKROKONTROLER KELAS XI KOMPETENSI KEAHLIAN TEKNIK AUDIO VIDEO DI SMK N. 1 LUBUK PAKAM
}

\author{
Sriadhi $^{1}$, Bakti Dwi Waluyo ${ }^{2}$, Kardo Simanjuntak ${ }^{3}$ \\ 1,2,3 Pendidikan Teknik Elektro \\ Prodi Pendidikan Teknik Elektro, Fakultas Teknik Universitas Negeri Medan \\ Email : kardo.juntak8@gmail.com
}

\begin{abstract}
Abstrak: Penelitian ini bertujuan untuk mengetahui bagaimana proses pengembangan Trainer Mikrokontroler sebagai media pembelajaran dan Menghasilkan trainer Mikrokontroler yang telah dikembangkan layak sebagai media pembelajaran. Penelitian ini menggunakan metode penelitian pengembangan research and development $(R \& D)$. Langkah-langkah pengembangan trainer arduino nano ini meliputi : (1) Potensi Dan Masalah, (2) Pengumpulan Data, (3) Desain Produk, (4) Validasi Desain, (5) Revisi Desain, (6) Uji Coba Produk, (7) Revisi Produk, (8) Uji Coba Pemakaian, (9) Revisi Produk, (10) Penetapan Kelayakan Trainer. Objek pada penelitian ini adalah Trainer Mikrokontroler Arduino Nano. Metode pengumpulan data pada penelitian ini menggunakan angket validasi uji persyaratan trainer dan uji validasi trainer. Uji persyaratan trainer dilakukan terhadap Ahli Praktisi dan uji validasi trainer dilakukan terhadap Ahli Media. Teknis analisis data yang digunakan pada penelitian ini adalah deskriptif kualitatif, kuantitatif dan statistik deskriptif. Hasil penelitian in adalah Trainer Mikrokontroler Arduino Nano yang terdiri dari piranti input sensor IR. Sensor cahaya dan piranti output seperti light emitting diode (LED), liquid crystal display (LCD) Matriks, Dot Matriks, Peragah Seven Segmen, Relay, Motor direct current (DC) dan Buzzer. Hasil uji persyaratan trainer oleh Ahli Praktisi sebesar 92,5\% (sangat layak) dan hasil uji validasi trainer oleh Ahli Media sebesar 91,25\% (sangat layak). Berdasarkan jumlah skor hasil uji persyaratan trainer dan hasil uji validasi media disimpulkan bahwa Trainer Mikrokontroler Berbasis Arduino Nano sangat layak digunakan sebagai media pembelajaran untuk kelas XI Teknik Audio Video di SMK Negeri 1 Lubuk Pakam.
\end{abstract}

Kata Kunci : Media Pembelajaran Trainer, Arduino Nano.

\begin{abstract}
This study aims to see how the process of developing a Microcontroller Trainer as a learning medium and producing a Microcontroller trainer that has been developed is feasible as a learning medium. This research uses research and development research and development $(R \& D)$ methods. The steps to develop this Arduino nano trainer include: (1) Potentials and Problems, (2) Data Collection, (3) Product Design, (4) Design Validation, (5) Design Revision, (6) Product Testing, (7) )) Product Revision, (8) Usage Trial, (9) Product Revision, (10) Determination of Trainer Eligibility. The object of this research is the Arduino Nano Microcontroller Trainer. The data test method in this study used a validation questionnaire to test the trainer requirements and the trainer validation test. Test of trainer requirements is carried out on Practitioners and trainer validation tests are carried out on Media Experts. The technical analysis of the data used in this research is descriptive qualitative, quantitative and descriptive statistics. The results of this research are the Arduino Nano Microcontroller Trainer which consists of IR sensor input devices, light sensors and output devices such as light emitting diode (LED), liquid crystal display (LCD) Matrix, Dot Matrix, Seven Segment Modeling, Relay, Direct Current Motor (DC) and Buzzer. The results of the trainer requirements test by Practitioners were $92.5 \%$ (very feasible) and the results of the trainer validation tests by Media Experts were $91.25 \%$ (very feasible). Based on the total score of the results of the trainer requirements and the results of the media validation test, it is stated that the Arduino Nano-based Microcontroller Trainer is very suitable to be used as a learning medium for class XI Audio Video Engineering at SMK Negeri 1 Lubuk Pakam.
\end{abstract}

Keywords: Trainer Learning Media, Arduino Nano.

\section{PENDAHULUAN}

Perkembangan teknologi yang sangat pesat di era globalisasi saat ini telah memberikan banyak manfaat dalam kemajuan diberbagai aspek sosial. Penggunaan teknologi oleh manusia dalam membantu menyelesaikan pekerjaan merupakan hal yang menjadi keharusan dalam kehidupan. Perkembangan 
teknologi ini juga harus diikuti dengan perkembangan pada Sumber Daya Manusia (SDM). Manusia sebagai pengguna teknologi harus mampu memanfaatkan teknologi yang ada saat ini, maupun perkembangan teknologi tersebut. Adaptasi manusia dengan teknologi baru yang telah berkembang wajib untuk dilakukan melalui pendidikan. Hal ini dilakukan agar generasi penerus tidak tertinggal dalam hal teknologi baru.

Pendidikan merupakan sebuah sarana yang efektif dalam mendukung perkembangan serta peningkatan sumber daya manusia menuju ke arah yang lebih positif. Kemajuan suatu bangsa bergantung kepada sumber daya manusia yang berkualitas, dimana hal itu sangat ditentukan dengan adanya pendidikan. Jika kualitas pendidikan tersebut rendah maka kualitas sumber daya manusia yang dihasilkannya kurang maksimal. Dalam meningkatkan kualitas pendidikan maupun pembelajaran lembaga pendidikan (sekolah) menjadi salah satu sarana yang penting dalam mewujudkannya. Salah satunya adalah Sekolah Menengah Kejuruan (SMK) yang merupakan suatu lembaga pendidikan yang berorientasi untuk menghasilkan individu-individu dengan kualitas sumber daya manusia yang memiliki tingkat kompetensi yang mampu diterima di dunia kerja/industri. Sekolah Menengah Kejuruan (SMK) termasuk dalam undangundang Sisdiknas No. 20 Tahun 2003 pada BAB 4, Bagian ketiga tentang pendidikan pendidikan menengah. Sekolah menengah kejuruan melaksanakan pendidikan sebagaimana diatur dalam Undang-Undang Sisdiknas Nomor 20 Tahun 2003 tentang sistem pendidikan nasional menyebutkan, Pendidikan adalah usaha sadar dan terencana untuk mewujudkan suasana belajar dan proses pembelajaran agar peserta didik secara aktif mengembangkan potensi dirinya untuk memiliki kekuatan spiritual keagamaan, pengendalian diri, kepribadian, kecerdasan, akhlak mulia, serta keterampilan yang diperlukan dirinya, masyarakat, bangsa dan negara. sebagai contoh Salah satu pendidikan kejuruan yaitu SMK Negeri 1 Lubuk Pakam yang terdapat di Kabupaten Deli Serdang Sumatera Utara dimana sekolah ini juga yang menjadi tempat landasan untuk diadakan penelitian. Sekolah ini memiliki beberapa bidang keahlian salah satunya bidang keahlian Teknik Audio vidio yang terdiri dari beberapa program keahlian dan kompetensi keahlian salah satunya adalah materi pembelajaran yang terdapat pada mata pelajaran Teknik Pemrograman, Mikroprosessor dan Mikrokotroler. Mata pelajaran teknik Teknik Pemrograman, Mikroprosesor Dan Mikrokontroler adalah salah satu mata pelajaran produktif disekolah menengah kejuruan (SMK) untuk kompetensi keahlian Teknik Audio Video. Mata pelajaran ini menjelaskan tentang pemrograman yang ada terkait pada mikroprosesor dan mikrokontroler.

Perlu diketahui bahwa mikroprosesor dan mikrokontroler merupakan sebuah alat yang dapat digunakan untuk membantu para teknisi dalam mempermudah membuat sebuah aplikasi elektronika. Mungkin pada zaman sebelum ditemukan mikroprosesor atau mikrokontroler para teknisi masih menggunakan rangkaian analog, namun seiring perkembangan zaman muncullah mikroprosesor dan mikrokontroler yang mempermudah membuat aplikasi elektronika menggunakan sistem digital dan mempermudah pengerjaan dibagian sistem industri. Hal tersebut yang menjadi salah satu mendorong untuk ditetapkan mata pelajaran sistem pemrograman, mikroprosesor dan mikrokontroler di Pendidikan kejuruan tepatnya Sekolah menengah kejuruan agar setiap siswa kelulusan pendidikan Kejuruan mampu memahami pemgrograman secara baik. Mengingat hal tersebut, SMK N. 1 Lubuk Pakam juga sudah menerapkan adanya mata pelajaran teknik pemrograman, mikroprosesor dan mikrokontroler dan mata pelajaran tersebut mulai ada pada Tahun 2017. Sudah kurang lebih 3 tahun mata pelajaran teknik pemrograman, mikroprosesor dan mikrokontroler diterapkan disekolah namun alat dan bahan yang digunakan sebagai contoh sekaligus bahan praktek belajar sampai saat ini juga masih belum ada sehingga menyebabkan siswa sama sekali kurang memahami secara mendalam mengenai teknik pemrograman, mikroprosesor dan mikrokontroler. Hal ini diketahui juga melalui wawancara terhadap siswa.

Berdasarkan wawancara yang dilakukan terhadap guru dan siswa potensi siswa kelas XI kompetensi keahlian Teknik Audio Video dalam bidang Mikroprosesor dan Mikrokontroler mayoritas siswa tergolong gaya belajar Auditori Dan guru mengajar yaitu dengan metode ceramah atau demontrasi dengan kata lain model pembelajarannya menggunakan model konvensional. Hal inilah 
pada akhirnya hasil belajar mereka masih terdapat yang tidak berkompeten dalam bidang mata pelajarannya dan pemahaman masih terbilang rendah. Diperoleh juga data bahwa, dalam pembelajaran Mikro-prosesor dan Mikrokontroler masih banyak siswa yang belum mencapai Kriteria Ketuntasan Minimal KKM yang ditetapkan yaitu 75 terbukti dari nilai rata-rata kelas yang hanya mencapai 65 , sementara dilihat dari ketuntasan individu berdasarkan KKM, dan data ini ternilai dari perolehan melalui 25 siswa hanya 11 orang siswa (44\%) yang telah mendapat nilai baik, sedangkan 14 orang siswa $(56 \%)$ belum mencapai KKM.

Wawancara yang dilakukan terhadap beberapa siswa kelas XI kompetensi Mikroprosesor dan Mikrokontroller mengenai Masalah yang di alami oleh siswa kelas XI kebanyakan dari mereka menyebutkan bahwa mereka jarang mengadakan praktek, sehingga ketika muncul pertanyaan apakah mereka mengenal bahasa pemrograman, jenis pemrograman apa yang diketahui, apakah pernah melakukan praktek mengenai pembuatan pemrograman sederhana seperti Led Berkedip, Running Led, mengontrol cahaya led dengan PWM, dan pemrograman lainnya lalu jawaban dari setiap siswa tidak mengetahui dan yang menjadi alasan mereka tidak mengatahui karena tidak ada praktek.

Pertanyaan juga muncul tentang apakah anda mengenal trainer, dan mereka juga serentak menjawab belum mengenal trainer karena belum adanya trainer di sekolah mereka. Hal ini Dikarenakan fasilitas sekolah yang belum memiliki trainer, masalah tersebut sangat menghambat siswa memahami materi pembelajaran didalam teori maupun praktik. Berdasarkan kondisi tersebut adanya potensi membuat trainer mikrokontroler sebagai media belajar yang diharapkan dapat menunjang kegiatan praktikum siswa sehingga proses belajar mengajar dapat dilakukan dengan lebih optimal.

Trainer Mikrokontroler ini sangat penting dan menarik untuk diteliti, trainer ini disertai dengan jobsheet (lembar kerja) agar dapat melatih logika pemrograman siswa untuk mendalami secara jelas mengenai pemrograman. Produk yang dihasilkan dalam penelitian ini adalah trainer Arduino Nano sebagai media pembelajaran untuk digunakan dalam kegiatan praktikum siswa.
Berdasarkan uraian di atas, maka penulis berinisiatif mengambil judul "Pengembangan Trainer Mikrokontroler Berbasis Arduino Nano Pada Mata Pelajaran Teknik Pemrograman, Mikroprosesor Dan Mikrokontroler Kelas XI Kompetensi Keahlian Teknik Audio Video Di SMK Negeri 1 Lubuk Pakam.

\section{METODE}

Metode penelitian yang digunakan dalam penelitian ini adalah metode penelitian pengembangan atau yang dikenal dengan Research And Development (R\&D). Prosedur penelitian pengembangan Trainer merujuk pada langkah-langkah penelitian pengembangan (Research and Development) oleh Sugiyono (2016:409), Yakni,

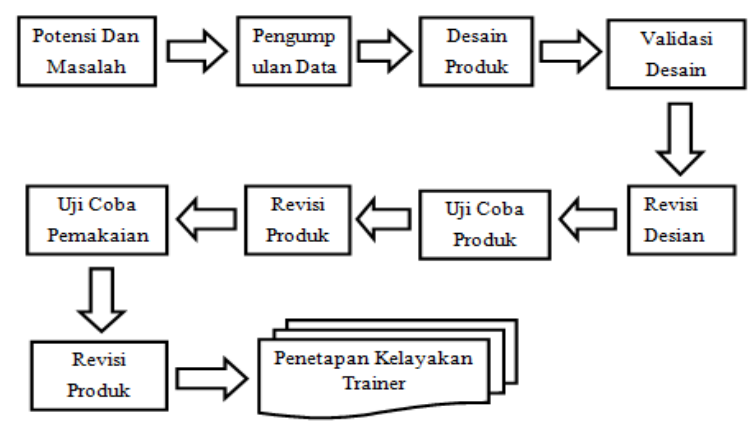

Gambar 1. Langkah-langkah Penelitian Pengembangan

Berdasarkan alur penelitian diatas maka langkah-langkah yang dilakukan adalah sebagai berikut:

1. Potensi Dan Masalah

Potensi adalah sesuatu yang bila didayagunakan akan memilih nilai tambah. sedangakan masalah adalah penyimpangan antara yang diharapkan dengan yang terjadi. Masalah ini dapat di temukan suatu model, pola, atau sistem penanganan terpadu yang efektif yang dapat digunakan untuk mengatasi masalah tersebut. Potensi dan masalah yang dikemukakan dalam penelitian harus ditunjukkan dengan data empirik.

2. Mengumpulkan Informasi

Setelah potensi dan masalah dapat ditujukan secara faktual dan uptodate, makaselanjutnya perlu di kumpulkan berbagai informasi yang dapat digunakan sebagai bahan untuk perencanaan produk tertentu yang di harapakan dapat mengatasi masalah tersebut.

3. Desian Produk

Desain produk yang dibuat harus lengkap dengan spesifikasinya. Desain produk harus di 
wujudkan dalam gambar dan bagan, sehingga dapat digunakan sebagai pegangan untuk menilai dan membuatnya.

\section{Validasi Desain}

Validasi desain merupakan proses kegiatan untuk menilai rancanga produk. Validasi produk dapat dilakukan dengan cara mengadirkan beberapa pakar atau tenaga ahi yang sudah berpengalaman untuk menilai produk baru yang dirancang tersebut. Setiap ahli diminta untuk menilai desain produk, sehingga selanjutnya dapat diketahui kelemahan dan kekuatannya. Validasi desain dpat dilakukan dalam forum diskusi.

5. Pebaikan Desain

Setelah desain produk divalidasi melalui diskusi dengan pakar dan para ahlinya, maka akan dapat diketahui kelemahannya. Kelemahan tersebut selanjutnya dicoba untuk dikurangi dengan cara memperbaiki desain.

6. Uji Coba Produk

Uji coba produk dilakukan dengan terlebih dahulu membuat wujud nyata produk kemudian menguji cobanya kepada responden skala kecil dengan pemilihan responden secara acak (random).

7. Revisi Produk

Setelah di uji coba skala kecil selesai, akan diketahui kelemahan produk pada tahap awal pengujian. Selanjutnyan kelemahan tersebut akan diperbaiki untuk meminimalkan kelemahan produk pada tahap selanjutnya.

8. Uji Coba Pemakaian

Uji coba pemakaian ini dilakukan pada skala yang lebih luas, maka jumlah responden lebih banyak dibandingkan dengan tahap uji coba skala kecil.

\section{Revisi Produk}

Revisi produk dilakukan apabila dalam uji coba pemakaian terdapat kekurangan atau kelemahan, sehingga kelemahan tersebut dapat digunakan menjadi bahan pertimbangan untuk memperbaiki produk.

10. Pembuatan Produksi Massal

Pembuatan produk massal ini di lakukan apabila produk telah di uji coba dinyatakan efektif dan layak untuk di produksi missal.

Teknik pengumpulan data yang dilakukan dalam penelitian ini adalah angket yang berisi pernyataan-pernyataan validasi. Angket menurut Sugiyono (20016:199) merupakan teknik pengumpulan data dengan cara memberikan pertanyaan atau pernyataan secara tertulis kepada responden untuk melihat produk yang telah dikembangkan. Angket berupa lembaran yang berisi kolom pernyataan, penilaian dan komentar. Nilai yang didapat dari responden akan digunakan sebagai analisis dalam pengujian kelayakan trainer dan komentar akan digunakan sebagai bahan pertimbangan dalam merevisi trainer. Angket validasi dalam penelitian ini juga digunakan sebagai instrumen penelitian karena pengujian dalam penelitian hanya sampai pada tahap validasi. Menurut Sugiyono (2016:148) instrumen penelitian merupakan alat ukur yang akan digunakan untuk mengukur fenomena alam maupun sosial yang diamati. Karena pada prinsipnya meneliti adalah kegiatan pengukuran, maka harus ada alat ukur yang baik. Instrumen yang digunakan dalam penelitian ini diadaptasi dari syarat trainer yang dikemukakan oleh Mourdel dalam Panahatan (2009:18) dan penelitian yang dilakukan oleh Riska Indarto (2015:47-52). Jenis instrumen pada penelitian ini terdiri dari angket uji persyaratan Trainer yang diadaptasi dari Mourdel, yaitu angket pendapat ahli oleh ahli media, praktisi dan pengguna yaitu guru maupun siswa.

Menurut Teknik analisa data yang dilakukan pada tahap pertama adalah menggunakan deskriptif kualitatif, yakni memaparkan produk media hasil rancangan media pembelajaran setelah di implementasikan dalam bentuk produk jadi. Tahap kedua menggunakan deskriptif kuantitatif, yakni mengubah data kualitatif menjadi kuantitatif, selanjutnya melakukan analisa kelayakan Trainer menggunakan statistik deskriptif dengan cara menghitung skor rata-rata hasil penilain tiap komponen pengembangan trainer.

Perhitungan statistik deskriptif dilakukan dengan cara mencari rerata skor total menggunakan rumus

$$
\bar{X}=\frac{\sum X}{n}
$$

$\bar{X}=$ Skor rata-rata jawaban responden

$\sum X=$ Jumlah skor jawaban

$n$ = Jumlah responden

Selanjutnya data yang didapatkan diubah ke dalam bentuk persen melihat persentase kelayakan Trainer yang dikembangkan. Rumus perhitungan pesentase skor ditulis dengan rumus berikut:

$$
\text { persentase kelayakan }(\%)=\frac{\text { Skor } \text { yang diobservasi }}{\text { Skor yang diharapkan }} \times 100 \%
$$

Selanjutnya, kategori kelayakan digolongkan menggunakan skala sebagai berikut: 
Tabel 1. interval kategori kelayakan

\begin{tabular}{|l|l|l|}
\hline No & $\begin{array}{l}\text { Skor dalam persen } \\
(\%)\end{array}$ & $\begin{array}{l}\text { Kategori } \\
\text { kelayakan }\end{array}$ \\
\hline 1 & $0 \%-25 \%$ & Tidak Layak \\
\hline 2 & $>25 \%-50 \%$ & Kurang Layak \\
\hline 3 & $>50 \%-75 \%$ & Layak \\
\hline 4 & $>75 \%-100 \%$ & Sangat Layak \\
\hline
\end{tabular}

\section{HASIL DAN PEMBAHASAN}

Penelitian dan pengembangan ini menghasilkan sebuah media pembelajaran berupa trainer mikrokontroler berbasis arduino nano. Tahap awal dalam pengembangan trainer mikrokontroler arduino nano adalah studi lapangan yaitu observasi dan wawancara terhadap guru di sekolah menengah kejuruan (SMK) N.1 Lubuk Pakam kompetensi keahlian teknik audio video. Observasi dilakukan dengan tujuan untuk mengidentifikasi kebutuhan dalam pembelajaran. Setelah diidentifikasi kemudian menganalisis apa yang menjadi kebutuhan guru maupun siswa dalam pembelajaran. Selanjutnya juga dilakukan analisis terhadap kurikulum untuk melihat kompetensi dasar materi pelajaran teknik pemrograman, mikroprosesor dan mikrokontroler, hal ini bertujuan untuk menyesuaikan isi dari pada pengembangan media pembelajaran (trainer) yang dirancang.

Penyesuaian pengembangan trainer mikrokontroler dengan kompetensi dasar mata pelajaran teknik pemrograman, mikroprosesor dan mikrokontroler didapat melalui kompetensi dasar yang digunakan guru sebagai acuan proses pembelajaran. Setelah studi lapangan selesai dilaksanakan, selanjutnya trainer dikembangkan derdasarkan data yang diperoleh dari studi tersebut. trainer mikrokontroler yang dikembangkan terdiri dari 2 modul yaitu, modul A dan modul B. Modul A adalah modul utama dimana terdapat piranti input/output seperti, LCD Matriks, LED, sensor LDR, Seven segment, Buzzer aktive dan passive, push buttong, relay, Elco $1000 \mathrm{~m} F \quad 16 \mathrm{~V}$, Resistor 10 K. Sedangkan pada modul B terdapat juga beberapa piranti seperti sebuah papan Arduino Uno beserta beberapa Piranti lainnya seperti Motor DC, Sensor IR. Setelah trainer mikrokontroler dikembangkan dan akhirnya selesai dibangun maka diadakan uji persyaratan untuk mengetahui apakah trainer yang dikembangkan telah memenuhi syarat sebagai alat pelatihan, dan uji kelayakan untuk mengetahui tingkat kelayakan trainer sebagai media, dengan menguji trainer mikrokontroler tersebut (memvalidasi) oleh orang yang berkompeten dalam bidang mikrokontroler yaitu Ahli Praktisi dan Ahli media.

\section{Hasil Uji Persyaratan Trainer Oleh Praktisi}

Validasi dilakukan dengan menggunakan angket uji persyaratan yang yang ditetapkan oleh Mourdel dalam Panahatan (2009:18). Berikut Tabel hasil validasi persyaratan trainer mikrokontroler oleh ahli praktisi.

Tabel 2. Hasil Uji Persyaratan Trainer Oleh

\begin{tabular}{|c|c|c|c|}
\hline \multirow{2}{*}{$\begin{array}{c}\text { No } \\
\text { Butir }\end{array}$} & $\begin{array}{c}\text { Skor } \\
\text { Maksimal }\end{array}$ & \multicolumn{2}{|c|}{ Pkor Praktisi } \\
\cline { 3 - 4 } & & $\begin{array}{c}\text { Ahli } \\
\text { Praktisi 1 }\end{array}$ & $\begin{array}{c}\text { Ahli } \\
\text { Praktisi 2 }\end{array}$ \\
\hline 1 & 4 & 4 & 4 \\
\hline 2 & 4 & 3 & 4 \\
\hline 3 & 4 & 4 & 3 \\
\hline 4 & 4 & 3 & 4 \\
\hline 5 & 4 & 4 & 4 \\
\hline \multicolumn{2}{|c|}{ Jumlah } & 18 & 19 \\
\hline \multicolumn{2}{|c|}{ Rata-Rata Skor } & 3,6 & 3,8 \\
\hline
\end{tabular}

setelah rata-rata skor dari masing-masing ahli praktisi maka selanjutnya diubah kedalam bentuk persen (\%) menggunakan rumus :

Persentase Kelayakan (\%) $=\frac{\text { skor yang diobservasi }}{\text { skor yang diharapkan }} \times 100 \%$

Maka hasil persentase uji persyaratan trainer oleh masing-masing ahli praktisi yaitu:

a. Ahli Praktisi 1

Persentase Skor $(\%)=\frac{3,6}{4} \times 100 \%=90 \%$

b. Ahli Praktisi 2

Persentase Skor $(\%)=\frac{3,8}{4} \times 100 \%=95 \%$

Setelah hasil persentase uji persyaratan didapat, selanjutnya dibandingkan dengan persentase persyaratan pada skala pengukuran yang digunakan untuk melihat kategori pemenuhan persyaratan trainer. Skala perbandingan tersebut dapat dilihat pada tabel.

Tabel 3. Persentase pemenuhan persyaratan.

\begin{tabular}{|c|c|c|}
\hline $\begin{array}{c}\text { No } \\
\text { Responden }\end{array}$ & Persentase & $\begin{array}{c}\text { Kategori } \\
\text { persyaratan }\end{array}$ \\
\hline Praktisi 1 & $90 \%$ & $\begin{array}{c}\text { Memenuhi } \\
\text { syarat }\end{array}$ \\
\hline Praktisi 2 & $95 \%$ & $\begin{array}{l}\text { Memenuhi } \\
\text { syarat }\end{array}$ \\
\hline $\begin{array}{l}\text { Rata-Rata } \\
\text { Persentase }\end{array}$ & $92,5 \%$ & $\begin{array}{l}\text { Sangat } \\
\text { memenuhi } \\
\text { syarat }\end{array}$ \\
\hline
\end{tabular}


Berdasarkan tabel diatas dapat diketahui hasil uji persyaratan trainer mikrokontroler oleh 2 orang ahli praktisi, ahli praktisi pertama sebesar $90 \%$ dan ahli praktisi kedua sebesar 95 $\%$, kemudian persentase dari ke-2 ahli dijumlahkan lalu dicari nilai rata-rata persentasenya maka didapat nilai $92,5 \%$, sehingga secara keseluruhan dapat disimpulkan bahwa trainer mikrokontroler memenuhi syarat kelayakan trainer yang baik dengan kategori Sangat memenuhi syarat.

\section{Hasil Uji Validasi Trainer Oleh Ahli Media}

Validasi media dilakukan oleh 2 orang ahli media dan. Hasil validasi dapat dilihat pada tabel dibawah ini.

Tabel 4. Skor Hasil Uji Validasi Media Oleh Ahli Media.

\begin{tabular}{|c|c|c|c|}
\hline \multirow{2}{*}{$\begin{array}{c}\text { No } \\
\text { butir }\end{array}$} & \multirow{2}{*}{$\begin{array}{c}\text { Skor } \\
\text { maksimal }\end{array}$} & \multicolumn{2}{|c|}{ Skor Ahli } \\
\cline { 3 - 4 } & & $\begin{array}{c}\text { Ahli } \\
\text { Media 1 }\end{array}$ & $\begin{array}{c}\text { Ahli } \\
\text { Media 2 }\end{array}$ \\
\hline 1 & 4 & 4 & 4 \\
\hline 2 & 4 & 3 & 4 \\
\hline 3 & 4 & 4 & 4 \\
\hline 4 & 4 & 3 & 3 \\
\hline 5 & 4 & 4 & 4 \\
\hline 6 & 4 & 4 & 3 \\
\hline 7 & 4 & 3 & 4 \\
\hline 8 & 4 & 4 & 3 \\
\hline 9 & 4 & 4 & 4 \\
\hline 10 & 4 & 3 & 3 \\
\hline 11 & 4 & 3 & 3 \\
\hline 12 & 4 & 4 & 4 \\
\hline 13 & 4 & 3 & 4 \\
\hline 14 & 4 & 4 & 4 \\
\hline 15 & 4 & 4 & 4 \\
\hline 16 & 4 & 4 & 4 \\
\hline 17 & 4 & 4 & 4 \\
\hline 18 & 4 & 4 & 4 \\
\hline 19 & 4 & 3 & 3 \\
\hline 20 & 4 & 3 & 4 \\
\hline & Jumlah & 72 & 74 \\
\hline Rata-Rata Skor & 3,6 & 3,7 \\
\hline & & & \\
\hline
\end{tabular}

Selanjutnya nilai rata-rata skor yang didapat dari masing-masing ahli media diubah dengan cara menghitung kedalam persen, berikut hasil persentase rata-rata skor ahli :

\section{1) Ahli 1}

Persentase Skor $(\%)=\frac{3,6}{4} \times 100 \%=90$ $\%$

2) Ahli 2

Persentase Skor $(\%)=\frac{3,7}{4} \times 100 \%=92,5 \%$

Hasil persentase skor dari masing-masing ahli media selanjutnya dibandingkan dengan skala pengukuran untuk melihat kategori kelayakan trainer. Hasil tersebut ditujukan pada tabel dibawah ini.

Tabel 5. Persentase Kelayakan Trainer Mikrokontroler

\begin{tabular}{|l|l|l|}
\hline $\begin{array}{l}\text { No } \\
\text { responden }\end{array}$ & Persentase & $\begin{array}{l}\text { Kategori } \\
\text { Kelayakan }\end{array}$ \\
\hline Ahli Media 1 & $90 \%$ & Sangat Layak \\
\hline Ahli Media 2 & $92,5 \%$ & Sangat Layak \\
\hline $\begin{array}{l}\text { Rata-Rata } \\
\text { Persentase }\end{array}$ & $91,25 \%$ & Sangat Layak \\
\hline
\end{tabular}

Berdasarkan tabel diatas dapat diketahui hasil uji validasi trainer mikrokontroler berdasarkan persentase kelayakan trainer oleh ahli media yaitu, ahli pertama sebesar $90 \%$, dan ahli kedua sebesar 92,5\%. Maka rata-rata persentase skor dari ke-2 ahli media tersebut yaitu sebesar 91,25\%, sehingga secara keseluruhan dapat disimpulkan bahwa trainer mikrokontroler layak digunakan sebagai media pembelajaran dengan kategori sangat layak.

\section{PENUTUP}

Trainer mikrokontroler arduino nano dikembangkan berdasarkan data hasil analisis kebutuhan dan kurikulum (kompetensi dasar) hal ini diperoleh dari studi lapangan di sekolah menengah kejuruan (SMK) Negeri 1 Lubuk Pakam kompetensi keahlian Teknik Audio Video, sehingga dihasilkan trainer mikrokontroler Arduino Nano yang terdiri dari piranti input seperti, sensor IR, sensor cahaya, pushh button dan piranti output seperti LED, LCD Matriks, Dot Matriks, Seven Segment, Relay, Buzzer, dan Motor DC. Setelah trainer selesai dibangun maka dilakukan uji validasi persyaratan trainer dan uji validasi media, hal ini dilakukan oleh orang yang berkompeten dibidang mikrokontroler yaitu Ahli Praktisi dan Ahli Media. Hasil uji persyaratan yang dilakukan oleh ahli Praktisi kedunya menyatakan bahwa trainer layak digunakan tanpa perbaikan dan data skor persentase yang diberi terhadap butir-butir aspek penilaian setelah dijumlahkan yaitu sebesar 92,5 \%dengan kategori sangat memenui syarat. 
Selanjutnya, hasil Uji validasi media oleh ahli media, data skor persentase yang diberi terhadap butir-butir aspek penilaian setelah dijumlahkan yaitu sebesar 91,25 \%dengan kategori sangat layak.

Berdasarkan hasil penelitian yang telah diuraikan di atas, ada beberapa hal yang dapat disarankan oleh peneliti demi meningkatkan pembelajaran, perlu adanya pelatihan terhadap guru-guru untuk dapat mengoperasikan mikrokontroler serta dapat mengembangkan trainer mikrokontroler, Perlu adanya kegiatan belajar tambahan untuk siswa/i yang bertujuan memperluas wawasan pemahaman mikrokontroler dan perlu adanya penelitian lebih lanjut dengan tampilan yang metode yang berbeda, menarik dan memotivasi siswa oleh peneli lainnya.

\section{DAFTAR PUSTAKA}

Cahyono, Nur. (2016). Pengembangan Trainer Sensor Sebagai Penunjang Mata Pelajaran Teknik Mikroprosesor Kelas X Progra Keahlian Elektronika Di Smk N 2 Pengasih. Skripsi. Universitas Negeri Yogyakarta Subdit Ristekdikti.

Indartato, Riska (2015). Pengembangan Trainer Mikrokontroler At89s51 Sebagai Media Pembelajaran Pada Mata Pelajaran Pada Mata Pelajaran Mikrokontroler Program Keahlian, Teknik Elektronika Industri Di Smk Negeri 1nanggulan. Skripsi Universitas Yogyakarta.

Panahatan. (2009). Pengembangan Modul Pembelajaran Untuk Meningkatkan Hasil Belajar Elektronika Dasar Siswa Program Keahlian Audio-Video Smk Swasta Teladan Medan. Tesis Magister, Universitas Negeri Medan.

Subdit Ristekdikti. Undang-Undang Republik Indonesia No. 20 Tahun 2003 Tentang Sistem Pendidikan Nasional. Diakses

Dari,Https://Kelembagaan.Ristekdikti.Go.Id/20 03/Uu-No-20-Tahun -2003-TentangSistem-Pendidikan-Nasional. 18 Februari 2020 Pukul 20:37

Sugiyono. 2016. Metode Penelitian Pendidikan Pendekatan Kuantitatif, Kualitatif, Dan $R \& D$. Bandung : Alfabeta. 